\title{
Considering the Present from the Past: On Mohist Thought and Its Modern Transformation
}

\author{
Lee Hsien-chung 李賢中 \\ Professor of Department of Philosophy, Vice Dean of College of Liberal Arts, \\ National Taiwan University, Taipei, Taiwan, China \\ hclee@ntu.edu.tw
}

\begin{abstract}
Pre-Qin era Mohist thought was endowed with a Confucian legacy as well as a critical eye and a unique set of ideas. These ideas later affected Legalist thought and attracted criticism from Mencius, Xunzi, and Zhuangzi, and many disputes arose thereafter between the later Mohists. Mohist thought can be broadly characterized as possessing distinctively ethical, rational, and practical features, and we can identify three main aspects of the modern transformation of Mohist philosophy. The first derives from Mozi's statement on "[the endeavor to] procure benefits for the world and eliminate its calamities," which can be interpreted as calling on humanity to resolve regional issues from a global viewpoint. The second draws upon Mozi's statement on "universal love and mutual aid" to promote a manner of thinking that embraces peace at a global level and cultivates strong worldwide environmental awareness. The third draws upon Mozi's ideas of "identification with the superior" and "Mohist methods of thinking" to promote a type of technological integration that incorporates cultural and social approaches and scientific thought to establish a global teaching system.
\end{abstract}

\section{Keywords}

all under Heaven - identification with the superior - innovation - Mohism universal love 


\section{Characteristics of Mohist Thought}

\subsection{The Spirit of "Universal Love"}

What is "universal love" [jian'ai 兼愛]? The chapter “Canon I [Jing shang 經上]" in the Mozi 墨子 says: "A $t i$ is a portion in a jian." The chapter "Explanations I [Jingshuo shang 經說上]" describes a $t i$ 體 as: "For example, one of two, or the starting point of a measured length." ${ }^{2}$ Here, jian 兼 denotes a whole, and $t i$ is a part thereof. As also stated in "Canon I": "Sun 損 [reduction/loss] is the removal of some without the rest."3 Mozi continues in the "Explanations I": "Some but not the rest: A $t i$ is a part of a whole [jian]." 4 These musings give us some insight into Mozi's conception of "universal love". It is a type of love bestowed on all of humanity, devoid of local particularity. As described in the chapter "Major Illustrations [Daqu 大取]" in the Mozi: “The love of many generations and the love of few generations are the same. In universal love it is also the same. The love of former generations and the love of future generations are the same as the love of the present generation." Looking at the relative emphasis here that "universal love" should not be confined by the era in which we live, we could describe the "scope" of universal love as encompassing all people, regardless of the vastness or smallness of the groups involved. Mozi's references to past generations, future generations, and those currently alive could be paraphrased as that the people who are the proper objects of universal love are not excluded from it by the time in which they exist - they should not be barred from universal love because of the limitation of having lived in the past or future. We observe here that Mozi's "universal love" is a type of love that transcends space and time and is targeted at all of humanity.

We clearly observe a distinction between the sense of equality on display here in Mozi's concept of "universal love" and concepts of love proposed by Confucian scholars who admit a difference in the degree of love to be properly shown toward others based on, for example, one's blood relationship to an individual. The "Major Illustrations" states: "Love everyone the same way you

1 Translation of this section taken from “經上-Canon I," trans. A. C. Graham, available at https://ctext.org/mozi/canon-i/.

2 Translation taken from “經上-Canon I," https://ctext.org/mozi/canon-i/.

3 Translation taken from "經上-Canon I," https://ctext.org/mozi/canon-i/.

4 Sun Yirang 孫詒讓, Mozi jiangu 墨子閒詁 [Inquiries and Interpretations of the Mozi] (Beijing: Zhonghua shuju, 1954), 213.

5 Ian Johnston, The Mozi: A Complete Translation (New York: Columbia University Press, 2010), 459 . 


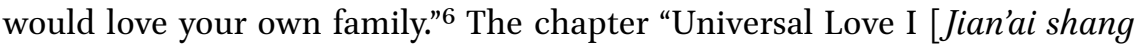
兼愛上]" in the Mozi also speaks about universal love as "When everyone regards other persons as his own person ... when everyone regards other families as his own family ... when everyone regards the houses of others as one's own ... when everyone regards the states of others as one's own." From this we observe that Mozi's conception of universal love is a form of love that places everyone on the same footing, taking no particular account of one's relationship to an individual, family connections or lack thereof, proximity, class, social ranking, or wealth. One aspect to this "equal love" is the sense of equality derived from "regarding others as you do oneself." Another aspect is a particular view that every individual is a person [ren 人] on an entirely equal footing from the vantage point of Heaven [tian 天].

We have also an opportunity to view the meaning of jian'ai from its various English translations:

1. Mei Yibao 梅貽寶 [1900-1997] and Chen Rongjie 陳榮捷 [1901-1994]: "Universal love." This phrasing emphasizes the universality and holistic nature of love. ${ }^{8}$

2. Stanford Encyclopedia: "Inclusive care." This phrasing emphasizes the non-exclusive and nondiscriminatory nature of jian'ai.

3. Heiner Roetz: "Co-love." This phrasing refers to the "mutually beneficial" and "cooperative" nature of love within jian'ai.

4. Angus C. Graham: "Concern for everyone." This phrasing highlights the fact that jian'ai is concerned about every single individual. ${ }^{9}$

These four approaches to translation of the term jian'ai help to illustrate its meaning from several perspectives. It is, in other words, a universal, nonexclusionary, mutual and practical concern for every individual.

Furthermore, Mozi's conception of the "mutuality of universal love" [jian xiang'ai 兼相愛] is often discussed alongside his conception of "mutual aid" [jiao xiangli 交相利]. $L i$ 利, the character for “aid" (or benefit) is related to $y i$ 義 [justice, morality, righteousness]; li refers to a public benefit and is a liy $i$ 利益 [benefit] with real-world, practical effects.

The spirit of universal love espoused by Mozi is concerned about both the attainment of practical and public benefits for all; Mozi here affirms the interactive nature of human relationships, for example, with the analogy "When

6 Translation taken from “大取-Major Illustrations," https://ctext.org/mozi/major-illustrations/.

7 Translation taken from “兼愛上-Universal Love I," https://ctext.org/mozi/universal-love-i.

8 Wing-Tsit Chan, A Source Book in Chinese Philosophy (Princeton: Princeton University Press, 1973), 212-13.

9 Sun Zhongyuan 孫中原, ed., Moxue yu xiandai wenhua 墨學與現代文化 [Mohism and Modern Culture] (Beijing: Zhongguo guangbo dianshi chubanshe, 2007), 216-18. 
a peach is thrown to us, we would return with a prune."10 As Professor Yan Lingfeng 嚴靈峰 [1903-1999] states: “In order to achieve universal love, both parties must also practice mutual love. Only this will prove sufficient to realize the ideal of 'universal love and mutual aid."11 Professor Yan here similarly highlights the principal of interactivity in Mozi's universal love. A more in-depth examination of the principle demonstrates that one of the parties involved must recognize the meaning of universal love and approve of the value of such an endeavor before this kind of interactivity can take place. That is, there must be proactive willingness to "love first" [xian'ai 先愛]; there is a proactive nature to universal love required to make the attainment of this mutually beneficial outcome possible. Mozi took the view that if all people were willing to practice care and concern for others, then this would naturally result in benefits for "all people under heaven" [tianxia ren 天下人].

\subsection{Characteristics of Mozi's Thought on "Names and Disputes"}

Mozi's thoughts on “names and disputes" [mingbian 名辯] are an important component of Mohist philosophy. Names and reasoning determine how we perceive shi 實 [the stuff, things, objects, reality of the actual world] and form their own branch of learning. Mozi states: "Names are used to explain stuff; phrases are used to express intention; explanations are used to bring out causes. Choose according to kind; offer according to kind." ${ }^{12}$ This is an effective, influential tool with which to persuade monarchs and to promote universal love and non-aggressive [feigong 非攻] thought.

The chapter “Lu's Questions [Luwen 魯問]" in the Mozi records:

I concluded that none of these is as good as to familiarize myself with the Tao of the ancient sage-kings, and discover their principles, and to understand the words of the sages and be clear about their expressions; and with these to persuade the rulers and then the common people. When the rulers adopt my principles their states will be orderly. When the common people adopt my principles their conduct will be regulated. ${ }^{13}$

\footnotetext{
10 Translation taken from “抑-Yi," https://ctext.org/book-of-poetry/yi/.

11 Yan Lingfeng 嚴靈峰, Mozi jianbian 墨子簡編 [Mozi Compendium] (Taipei: Shangwu yinshu guan, 1995), 36 .

12 Translation taken from “小取-Minor Illustrations," https://ctext.org/mozi/minor -illustrations/.

13 Translation taken from “魯問 - Lu's Question,” https://ctext.org/mozi/lus-question/.
} 
There is a very practical aspect to Mozi's exploration of the words of the sage-kings. Mozi was using the ideas of the ancient sages and sage-kings to try to have a persuasive effect on the members of all classes during this Warring States period $\left[475^{-221} \mathrm{BCE}\right]$ to the effect that we should all "understand the words of the sages" - that is, to examine the meaning and significance of their words. Mozi provides further explanation for names and disputations thought in his chapter "Minor Illustrations [Xiaoqu 小取].”

The chapter states:

Distinguishing will be used to make clear the distinction between so and not so; investigate the rules of order and chaos; make clear the locations of similarity and difference; examine the patterns of name and stuff; locate benefit and harm, and resolve doubts. Only then can one describe in approximation the way the myriad things are, and speak of seeking similarity of sayings. Names are used to raise stuff; phrases are used to express intention; explanations are used to bring out causes. Choose according to kind; offer according to kind. ${ }^{14}$

Mozi's reference to the term shuo 說 [to say, express or explain] in his statement "explanations [shuo] are used to bring out causes" implies a significant amount of persuasive debate and analysis. In terms of the particular characteristics of Mozi's names and disputes, the debating methods of analogy [ $p i$ 辟], similarity [mou 侔], leading [yuan 援], and extending [tui 推] raised in the "Minor Illustrations" are all essentially analogical methods aimed at facilitating negotiation and persuasion after one masters the criteria one's counterpart can acknowledge according to the principal of "knowing one's opponent" [zhibi 知彼]. This approach could be applied to politics, diplomacy, economics, education, the environment, and so forth.

\subsection{Practical Guidance}

How should the Mohist method of three standards [sanbiao fa 三表法] be applied? According to Mozi: "It is to be applied by adopting it in government and observing its benefits to the country and the people." 15 The three Mohist standards give us a particular metric that reveals the Mohist emphasis on

\footnotetext{
14 Translation taken from “小取-Minor Illustrations,” https://ctext.org/mozi/minor -illustrations/.

15 Translation taken from “非命上-Anti-Fatalism I,” https://ctext.org/mozi/anti-fatalism-i/.
} 
yong 用 [use or application]. Mohism's practical guidance is chiefly expressed in two areas.

First, Mozi argued that people are composed of a physical body and a mind. We observe Mozi's use of the character xing 形 [body] in multiple places in his Mozi canons as indicating the purposeful bent of his theories - to the improvement of the people's material living conditions. For example, we see Mozi identify three worries [ huan 患] that people suffer in the chapter "Against Music I [Feiyue shang 非樂上]": "The hungry cannot be fed, that the cold cannot be clothed, and that the tired cannot get rest."16 And we also observe that Mozi's ideas in "Against Music" as well as in many of his other works were concerned with the aim of eradicating such evils from the society. The chapter "Lu's Questions" states:

Gongshu zi constructed a bird from bamboo and wood and when it was completed he flew it. It stayed up [in the air] for three days. Gongshu zi was proud of his supreme skill. Mozi said to him: Your accomplishment in constructing a bird does not compare with that of the carpenter in making a linchpin. In a short while he could cut out the piece of wood of three inches. Yet it would carry a load of fifty shi. For any achievement that is beneficial to man is said to be beautiful, and anything not beneficial is said to be clumsy. ${ }^{17}$

On occasion, Mozi had to craft numerous farming implements, devices, military defensive chariots, weapons, and some technical tools. This shows that all such creations, whether related to physical capabilities [tineng 體能], property and assets [zicai 資財], or tools [ $q i w u$ 器物], were, in Mozi's eyes, beneficial to the people. The use of tineng was found in refining a healthy physique, thereby infusing an individual with abundant strength to undertake such endeavors as would benefit wider society; the use of assets and devices is to be found in satisfying the everyday needs of the people for the purpose of attaining greater safety, convenience, comfort, and so on. Thus, the modern significance of xing in modern Mohist thought emphasizes the possession of good health, ample necessities, and a convenient living environment and circumstances.

Second, turning to Mozi's concept of $z h i$ 智 [mind], Mohist thought facilitated the development of a perspective on happiness somewhat geared to the

16 Translation taken from “非樂上-Condemnation of Music I," https://ctext.org/mozi/ condemnation-of-music-i/.

17 Translation taken from “魯問-Lu's Question,” https://ctext.org/mozi/lus-question/. 
limitation of personal desire. Mozi's ideas on "frugality" [jieyong 節用] and "frugality in funerals" [jiezang 節葬] in particular can be viewed from the role of $z h i$ in restraining people's desires. “Happiness” [xingfu 幸福] here correlates positively with "what is obtained" [suode 所得] but negatively with “desire” [yuwang 欲望]. Thus, assuming a situation in which "what is obtained" remains unchanged, if one's desire decreases, then the happiness that one can obtain concomitantly increases. In reality, however, what people "obtain" differs quite significantly. Mozi's thinking in "Against Fatalism [Feiming 非命]" and "Valuing Rightness [Guiyi 貴義]" show that he encouraged people to strive enthusiastically and to work hard to increase what they could obtain. These efforts increase, on the one hand, the bounty that individuals obtain for themselves and, on the other, limit individuals' inflated sense of desire that would normally accompany such an increase (assuming a Mohist approach), thus tending to increase people's happiness. The "Canon I" also notes that: " $L i$ is what one is pleased to get." 18 Naturally, the term de 得 [to get or obtain] here does not merely refer to things of a financial or material nature. The chapters "Universal Love" and "Will of Heaven [Tianzhi 天志]" in the Mozi show that this de can also include, for example, respect from others and the commendation of Heaven - that is, things that require people to maintain excellent, caring relationships with those around them - as well as habits in the world that comport with moral and ethical principles - that is, the rightness desired by Heaven.

We hereby obtain a glimpse of a holistic view of the ethical, rational, and practical elements that characterize Mohist thought. The ethical aspect of Mozi's thought is evident from his concept of "universal love," the rational aspect of Mozi's thought from his "names and disputes," and the practical aspect from Mozi's holistic physical and mental perspective on human beings.

\section{$2 \quad$ Pre-Qin Era Critiques of and Responses to Mohist Thought}

The Mohist School appears to have been very prominent along with the Confucians during the Warring States period, as reflected in this statement in the "Eminence in Learning [Xianxue 顯學]" chapter in the Han Fei $z i$ 韓非子: "In the present age, the celebrities for learning are the Literati and the Mohists. The highest figure of the Literati was Kung Chiu; the highest figure of the

18 Translation taken from “經上-Canon I,” https://ctext.org/mozi/canon-i/. 
Mohists was Mo Ti."19 The status of Mozi and Mohist thought as a prominent philosophy [xianxue 顯學] at the time inevitably meant that Mohist thought would both have influence on and be criticized by contemporary and later scholars.

\subsection{Mencius's Critique of Mohism}

Mencius [372-289 BCE] launched a vigorous critique of Mozi, stating:

Again the world fell into decay, and principles faded away. Perverse speakings and oppressive deeds waxed rife again.... Once more, sage sovereigns cease to arise, and the princes of the States give the reins to their lusts. Unemployed scholars indulge in unreasonable discussions. The words of Yang Zhu and Mo Di fill the country. If you listen to people's discourses throughout it, you will find that they have adopted the views either of Yang or of Mo. Now, Yang's principle is "each one for himself," which does not acknowledge the claims of the sovereign. Mo's principle is "to love all equally," which does not acknowledge the peculiar affection due to a father. But to acknowledge neither king nor father is to be in the state of a beast. $^{20}$

Mencius was of the view that Mozi's conception of universal love was in contradiction to human nature. If we viewed and treated others with the same compassionate eyes and actions as we treat and view our own parents, for example, then this would be tantamount to a rejection and abandonment of the familial affections that are properly part of "the natural relationship appropriate to father and son" [ fuzi renlun 父子人倫] and in violation of filial piety. One of Mozi's followers, Yi Zhi 夷之, mounted a defense on Mozi's behalf.

As the “Teng Wen Gong I 滕文公上” chapter in the Mencius 孟子 records:

Yi said, "Even according to the principles of the learned, we find that the ancients acted towards the people 'as if they were watching over an infant.' What does this expression mean? To me it sounds that we are to love all without difference of degree; but the manifestation of love must begin with our parents." Xu reported this reply to Mencius, who said, "Now, does Yi really think that a man's affection for the child of his

19 Translation taken from W. K. Liao, The Complete Works of Han Fei Tzŭ with Collected Commentaries (London: Probsthain, 1939), 336.

20 Translation taken from “滕文公下-Teng Wen Gong II," https://ctext.org/mengzi/teng -wen-gong-ii/. 
brother is merely like his affection for the infant of a neighbor? What is to be approved in that expression is simply this: that if an infant crawling about is likely to fall into a well, it is no crime in the infant. Moreover, Heaven gives birth to creatures in such a way that they have one root, and Yi makes them to have two roots. This is the cause of his error."21

As Yi Zhi's “discussion of motivation and effects" [zhigong weibian 志功為辯] perspective illustrates, there is a point of comparison between the Mohists and Confucians in that this love borders on the Confucian view of a sage-king who looks upon his people as his own children and that universal love, practically speaking, must begin with our surrounding family and relatives. Mencius opposed this approach because, as per his account, the children of one's own brother are fundamentally different from the children of one's neighbor due to their respective parentage, and the familial affection [qin qing 親情] of blood relationships has its own independent natural basis.

\subsection{Xunzi's Critique of Mohism}

The "Against the Twelve Masters [Fei shi'er zi 非十二子]" chapter in the Xunzi 荀子 states:

Some of these men do not understand the proper scales for unifying the world and establishing states and families. They elevate concrete results and usefulness, and they extol frugality and restraint. But they have disdain for ranks and classes, and so they have never been able to accept distinctions and differences, or to discriminate between lord and minister. Nevertheless, they can cite evidence for maintaining their views, and they achieve a reasoned order in their explanations, so that it is enough to deceive and confuse the foolish masses. Just such men are Mo Di and Song Xing. ${ }^{22}$

Xunzi 荀子 [313-238 вСE] believed that Mohist thinking contained too great an emphasis on self-restraint, to the point of overlooking differences between different groups in society, such as between the higher and lower classes, ignoring the natural distinctions in and between human relationships, to the point that even the relationships between the ruler and his ministers were not sufficiently distinguished. From Xunzi's perspective, where $l i$ 禮 [propriety]

21 “滕文公上-Teng Wen Gong I," https://ctext.org/mengzi/teng-wen-gong-i/.

22 Translation taken from Eric L. Hutton, Xunzi, the Complete Text (Princeton: Princeton University Press, 2014), 40. 
should establish an orderly society, Mozi's theories would have the effect of deceiving and confusing the people, although it was not without reasonable merit in certain respects.

The chapter “On Enriching the State [Fuguo 富國]" in the Xunzi records:

In his teachings, Mozi worries very conspicuously about insufficiency for the whole world. However, insufficiency is not the common disaster facing the world. That is only Mozi's individual worry and erroneous reckoning. Now the way this soil gives birth to the five grains is such that if people tend it well, a single $m u$ of land will yield several bushels, and within a single year one can have two harvests.... Beyond these, the flying birds, ducks, and swans can become [so numerous as to be] like billows of smoke in the sky. Beyond these, the insects and other myriad creatures live in the remaining space. Among all these, there are countless that are edible. So, the way Heaven and Earth give birth to the myriad things is such that there is originally an abundance sufficient to feed people. The fibrous plants and silk and the feathers, fur, teeth, and shells of the animals are originally in abundance sufficient to clothe people. So the question of abundance or insufficiency is not the common disaster facing the world. That is only Mozi's individual worry and erroneous reckoning. ${ }^{23}$

Here, Xunzi raises several criticisms as to the emphasis on frugality and saving in Mohist thought, believing Mozi to be excessively concerned with the travails of insufficient food and clothing. Xunzi is focusing here on the fact that the main determining factor involved in whether the individuals concerned are skilled at the work of production and using the factors of favorable geographic conditions and timing [tianshi dili 天時地利] to increase production or yield. He also makes the point that, in reality, the bounty of nature is sufficient for human society's uses. The "Discourse on Heaven [Tianlun 天論]" in the Xunzi records: "Mozi saw the value of making things uniform, but did not see the value of establishing differences." ${ }^{24}$ Xunzi also states in the "Dissolving Partiality [Jiebi 解蔽]" chapter of the Xunzi that: "Mozi is blinded by utility and insensitive to good form." ${ }^{25}$ Here, Xunzi is laying criticism on what, in his eyes, is Mozi's blindness to disparities between human relationships due to a singular

23 Translation taken from Hutton, Xunzi, 184-85.

24 Translation taken from Hutton, Xunzi, 274.

25 Translation taken from Carine Defoort, "Do the Ten Mohist Theses Represent Mozi's Thought? Reading the Masters with a Focus on Mottos," Bulletin of the School of Oriental and African Studies 77, no. 2 (2014): $35^{6}$. 
focus on putting everyone on an equal level. Furthermore, Mozi is focused only on the practical aspects of manners to the neglect of cultural and literary cultivation [renwen xiuyang 人文修飬]. The chapter "Discourse on Music [Yuelun 樂論]” in the Xunzi states:

To control desire with morality enables one to be happy and not dissolute; to forget morality to satisfy our desires is to become lost and not joyous. And so music is used as a guide toward the people's entertainment. Bells and drums, flutes and chime-stone, lutes and zithers are used as a guide towards ethical cultivation. The promotion of music has promoted morality amongst the people. So music is a major tool in the governance of the people, and yet Master Mo opposes it. ${ }^{26}$

Xunzi advocated that music be an instrument because of its role in the ethical cultivation of the human heart [jiaohua renxin 教化人心] and guiding the people toward benevolent endeavors. For Xunzi, music was a pathway for mollifying the people's desires to help establish a more orderly society, yet Mozi seemed to disagree.

The chapter "On Enriching the State" states:

The common disasters of the world are inflicted by disorder. Why not attempt to locate the authors of such disorder? I am of the view that Master Mo's opposition to music will promote general disorder. $\mathrm{He}$ advocates frugality, which would leave the world poorer.... If Master Mo were in charge of the earth or its kingdoms, then the number of servants would be reduced, officialdom diminished, and difficult work and frugality promoted such that these [people of high rank] would do the same work as the ordinary person. This would deprive the monarch of his stature; without the monarch's stature, then lawbreakers would not receive their punishment. If there is no effective commendation, then the sagelike person will not be employed and promoted; if there is no effective punishment, then those who are lack such [sage-like] qualities cannot be removed. If the sage-like person cannot be [gainfully] used, and the unsage-like cannot be removed, then there is a lack of appropriate utilization for those who have ability and those without. ${ }^{27}$

26 Wang Xianqian 王先謙, Xunzijijie 荀子集解 [Collected Explanations of the Xunzi], coll. Shen Xiaohuan 沈嘯寰 and Wang Xingxian 王星賢 (Beijing: Zhonghua shuju, 1988), 382. Wang Xianqian, Xunzi jijie, $185^{-86 .}$ 
Here, Xunzi illustrates his view that Mozi's emphasis on frugality and opposition to music will make it difficult for people to satisfy their desires. For instance, if we were to reduce the salaries given to officers of the state sizably in order to encourage greater frugality and for senior members of society to engage in hard physical work alongside the common folk, this will also strip officials of much of their dignity and authority, the very authority that enables these officials to dispense commendations or punishments to commendable or deplorable members of society. Without such systems of commendation or punishment, we must then become concerned about how the country can be governed effectively.

\subsection{Zhuangzi's Critique of Mohism}

The "The Adjustment of Controversies [Qiwu lun 齊物論]" chapter in the Zhuangzi 莊子 states:

Dao becomes obscured through the small comprehension [of the mind], and speech comes to be obscured through the vaingloriousness [of the speaker]. So it is that we have the contentions between the Literati and the Mohists, the one side affirming what the other denies, and vice versa. If we would decide on their several affirmations and denials, no plan is like bringing the [proper] light [of the mind] to bear on them. ${ }^{28}$

Here, we can see Zhuangzi's 莊子 [ca. 369-286 вСE] view that the Confucians and Mohists are fortifying their own positions without much regard to "reaching out," from which vantage point their critiques are thus mounted. The problems in the other side's conceptions that each seeks to lay clear is merely working out their own prior biases. In reality, a scholar can see through such preconceptions only with the light of a calm and collected heart and understanding of the Dao that takes a more general picture into account.

The “Tian Xia 天下” chapter in the Zhuangzi records:

Mo-zi, in praise of his views, said, "Anciently, when Yu was draining off the waters of the flood, he set free the channels of the Jiang and the He, and opened communications with them from the regions of the four Yi and the nine provinces. The famous hills with which he dealt were 300 , the branch streams were 3000 , and the smaller ones innumerable. With his own hands he carried the sack and wielded the spade, till he

28 Translation taken from “齊物論-The Adjustment of Controversies," https://ctext.org/ zhuangzi/adjustment-of-controversies/. 
had united all the streams of the country [conducting them to the sea]. There was no hair left on his legs from the knee to the ankle. He bathed his hair in the violent wind, and combed it in the pelting rain, thus marking out the myriad states. Yu was a great sage, and thus he toiled in the service of the world." The effect of this is that in this later time most of the Mohists wear skins and dolychos cloth, with shoes of wood or twisted hemp, not stopping day or night, but considering such toiling on their part as their highest achievement. They say that he who cannot do this is acting contrary to the way of $\mathrm{Yu}$, and not fit to be a Mohist.... They would have made the Mohists of future ages feel it necessary to toil themselves, till there was not a hair on their legs, and still be urging one another on; [thus producing a condition] superior indeed to disorder, but inferior to the result of good government. Nevertheless, Mo-zi was indeed one of the best men in the world, which you may search without finding his equal. Decayed and worn [his person] might be, but he is not to be rejected - a scholar of ability indeed! ${ }^{29}$

Here, we see that in Zhuangzi's estimation the Mohist ideal is unattainable, albeit perhaps worthy of aspiration; and although the Mohists might cultivate a self-sacrificial spirit, this is to no great end.

From the preceding we can make out roughly four main areas of criticism of Mohist philosophy. First, universal love violates human nature and presents an impediment to filial piety. Second, Mozi downplays or overlooks the importance of propriety and music in the establishment of an orderly society. Third, Mohist thought has undergirded itself with too narrow and confined a perspective. And, fourth, the Mohist ideal is set far too high and is unattainable in reality. Let us now turn to a deeper examination of the reasoning in these critiques from the Mohist perspective.

\section{$2.4 \quad$ Responses to These Critiques}

To begin with, we might ask whether universal love really contradicts human nature, which must provoke another question: what is really meant by human nature? The "Yang Huo 陽貨” chapter in the Analects states: “The Master said, 'By nature, men are nearly alike; by practice, they get to be wide apart."'30 Confucius does not make a clear pronouncement on the essential characteristics of human nature, only that human beings are rather like one another in their nature. Confucius also highlights the potential for every human being to

29 Translation taken from “天下-Tian Xia," https://ctext.org/zhuangzi/tian-xia/.

30 Translation taken from “陽貨-Yang Huo," https://ctext.org/analects/yang-huo/. 
do good, stating in the "Transmitting [Shu er 述而]" chapter in The Analects: "The Master said, 'Is virtue a thing remote? I wish to be virtuous, and lo! virtue is at hand."'31 A key takeaway here is that the decision to do good or evil rests with individuals' decisions, one that stems from their will. Conversely, Confucius is very mindful of the potential for individuals to do harm, for example, as recorded in the "Yan Yuan 顏淵" chapter in The Analects:

The Master said, "To subdue one's self and return to propriety, is perfect virtue.... Is the practice of perfect virtue from a man himself, or is it from others?" The Master replied, "Look not at what is contrary to propriety; listen not to what is contrary to propriety; speak not what is contrary to propriety; make no movement which is contrary to propriety."32

As discussed here, human behavior often violates the standards of "propriety." Xunzi inferred a dark aspect to the human heart stemming from $y u$ 欲 [desire]; in his “Four Sprouts of Xin [Siduan zhixin 四端之心]," Mencius theorized that human nature was essentially good, whereas Mozi emphasized the importance of learning (as a matter of nurture rather than nature). For example, as stated in the "Canon II": "Learning is of benefit. The explanation for this may be found from the one criticizing." ${ }^{33}$ Learning is beneficial because the voice of the critic also contributes to the act of teaching others how to learn. Mozi opposed the trend in his day in which "learning is of no benefit" [xue wuyi 學 無益], as reflected in the "Canon I": "Life is the body being located with the intelligence." 34 Mozi's concept of the human being encompassed two aspects: a "physical body" [xingti 形體] and “mind" [zhili 智力], and it is through "nurtured" learning (relying on these two areas of human capability) that different means of gaining knowledge comes through "explanation" [wenzhi 聞知], “hearsay" [shuozhi 說知], and "personal experience" [qinzhi 親知]. People then use "the name" [mingzhi 名知], “the object" [shizhi 實知], and "how to relate" [hezhi 合知] to implement this knowledge into the reality of everyday life. As the "Canon I" states: "Zhi [know]. By hearsay, by explanation, by personal experience. The name, the object, how to relate, how to act"35 - that is, knowledge. The chapter "Will of Heaven III" states: "And Mozi said: Be obedient. Be careful.

31 Translation taken from “述而-Shu er," https://ctext.org/analects/shu-er/.

32 Translation taken from “顏淵-Yan Yuan," https://ctext.org/analects/yan-yuan/.

33 Sun Yirang, Mozi jiangu, 208.

34 Translation taken from “經上-Canon I," https://ctext.org/mozi/canon-i/.

35 Translation taken from “經上-Canon I," https://ctext.org/mozi/canon-i/. 
Be sure to do what Heaven desires and avoid what Heaven abominates." 36 The words wei 為 [to do on behalf of] and qu 去 [to avoid or remove] depend on the free volition of an individual's choice to choose good and avoid evil. Hence, we might say that Mozi's conception of human nature, with its emphasis on the level of “intellect or rationality” [zhixing 知性] and “will” [yizhi 意志] of a human being, is not necessarily incompatible with Confucian thought. The chapter "Universal Love III" records the following response with respect to whether Mohist philosophy contravenes filial piety:

Mozi replied: Now let us inquire about the plans of the filial sons for their parents. I may ask, when they plan for their parents, whether they desire to have others love or hate them? Judging from the whole doctrine [of filial piety], it is certain that they desire to have others love their parents. Now, what should I do first in order to attain this? Should I first love others' parents in order that they would love my parents in return, or should I first hate others' parents in order that they would love my parents in return? Of course I should first love others' parents in order that they would love my parents in return. Hence those who desire to be filial to one another's parents, if they have to choose (between whether they should love or hate others' parents), had best first love and benefit others' parents. ${ }^{37}$

Although the ethical conceptions might not be a perfect match, we still might be able to declare that universal love is not in violation of filial piety [xiaodao 孝道] when we consider the motivations and effects in Mozi's "discussion of motivation and effects" as well as the "authority" [quan 權] tradeoffs involved..$^{38}$ Looking at the ideals embedded in universal love, the long-term promotion and realization of universal love would certainly encourage a general or universal sense of filial piety from the perspective of a more expansive landscape in time and space.

Let us next turn to the question of whether Mozi was really ignorant of the important role played by propriety and music in establishing social order. Mozi's "identification with the superior" [shangtong 尚同] and "conformity to the sages" [shangxian 尚賢] demonstrate his concern about removing the

36 Translation taken from “天志下-Will of Heaven III," https://ctext.org/mozi/will-of -heaven-iii/.

37 Translation taken from “兼愛下-Universal Love III," https://ctext.org/mozi/universal -love-iii/.

38 Lee Hsien-chung 李賢中, Moxue lilun yu fangfa 墨學理論與方法 [Mohism: Theory and Method] (Taipei: Yangzhi wenhua shiye gufen youxian gongsi, 2003), 140-42. 
ills of chaos in the world [tianxia zhiluan 天下之亂] in the establishment of an orderly society. This normative template on which Mozi focused is based on, on the one hand, a transcendent will of Heaven [tianzhi 天志] as the supreme standard [ fayi 法儀] and, on the other hand, the instinctive desire of all people to cleave to the good and avoid harm or evil, an instinct also motivated by the commendation and punishment of heaven and those in higher positions. Mozi did not comprehensively negate the role played by "propriety" and "music." His was a partial rejection, as recorded in the chapter "On Ghosts III [Mingguixia 明鬼下]" in the Mozi:

While he was working in the temple, a wizard carrying a cane appeared and said to him: “Guan Gu, why don't the jades and stones measure up to the standard, and why are the cakes and wine unclean, and the victims imperfect and not fat, and the sacrifices not in season?"39

This passage reveals Mozi's appreciation of the finer details of "sacrifice" [jili 祭禮]. Regarding Mozi's apparently "anti-music" philosophy, we would also do well to look at this question with regard to issues of fairness (or the lack thereof) across the wider society. Indeed, the dukes and nobility in those days were known for profligate, wasteful lifestyles that contributed to a shortage of food and sufficient clothing for the average person. As also recorded in the chapter "Against Music I": "There are three things that the people worry about, namely, that the hungry cannot be fed, that the cold cannot be clothed, and that the tired cannot get rest. These three are the great worries of the people." 40 It also appears evident that Mozi was well aware of the power of "musical activities" to bring people comfort and joy. As recorded in the chapter "Against Music I":

So the reason ... Mozi condemns music is not [that] that the sounds of the big bell, the sounding drum, the qin and the se and the $y u$ and the sheng are not pleasant, that the carvings and ornaments are not delightful, that the fried and the broiled meats of the grass-fed and the grain-fed animals are not gratifying, or that the high towers, grand arbors, and quiet villas are not comfortable. Although the body knows they are comfortable, the mouth knows they are gratifying, the eyes know they are delightful, and the ears know they are pleasing, yet they are found not to be in accordance with the deeds of the sage-kings of antiquity and not

39 Translation taken from “明鬼下-On Ghosts III," https://ctext.org/mozi/on-ghosts-iii/.

40 Translation taken from “非樂上-Condemnation of Music I," https://ctext.org/mozi/ condemnation-of-music-i/. 
to contribute to the benefits of the people at present. And so Mozi proclaims: To have music is wrong. ${ }^{41}$

We can see here that Mozi was not entirely opposed to propriety and music [liyue 禮樂] but, rather, was particularly mindful of the surrounding everyday living conditions under which it was to be practiced. For example, Mozi's philosophy of frugality in funerals opposed ornate funerals involving excessively long periods of mourning because this incurred an unreasonably difficult burden on the average person.

Did Mozi establish too narrow and restrictive a philosophy? We can observe a repeated emphasis in every section of Mozi's canon: "The purpose of the magnanimous lies in procuring benefits for the world and eliminating its calamities." $^{22}$ This statement indicates the sheer vastness of Mozi's vision and the heights of Mohist ideals. Many other philosophies have come into conception with the underlying backdrop created by Mohist thought, and many alternative theories that would resolve problems of the day also had substantial limitations. For instance, Xunzi, Mozi's critic, appears to suffer from similar theoretical deficiencies, and Xunzi's theories on the evil of human nature do not reflect philosophical aspects inherited from Confucius. We might as well declare that Mozi put forward a philosophy on a level hitherto unseen in other pre-Qin dynasty [before $221 \mathrm{BCE}$ ] scholars, with a positive impact on the time in which he lived.

Let us now turn to the question of whether Mohist thought is excessively idealistic, overly bound by formulaic precepts, and unattainable in reality. To begin with, our assessment of a particular school of thought cannot be judged based on the criterion of whether its ideals are achievable because this is also a fate that has befallen many of humanity's ideals to this day, including the "unity of man and nature" [tianren heyi 天人合一] of the Confucians, the "ascending to the Dao" [dengjia yudao 登假於道] of the Daoists, and the ethereal plane and paradigmatic ideals of the "sages" [shengren 聖人], "mighty ones" [daren 大人], "supreme ones" [zhiren 至人], and "celestials" [shenren 神人], which are often unachievable by the average person. But such a school of thought should not thereby lose its value. Similarly, the Mohist ideals of "universal love and mutual aid" and "procuring benefits for the world and eliminating its

41 Translation taken from “非樂上-Condemnation of Music I," https://ctext.org/mozi/ condemnation-of-music-i/.

42 Translation taken from “尚同中-Identification with the Superior II," https://ctext.org/ mozi/identification-with-the-superior-ii/. 
calamities" have not been generally realized as yet but may still retain value as that which aspiring individuals in each successive generation can continue to work toward and hope to achieve.

\section{3}

\section{Han Fei's Repurposing of Mohist Philosophy}

\subsection{The Use and Repurposing of the Mohist Standards in the Han Fei zi}

The "On the Necessity of Standards [Fayi 法儀]" chapter in the Mozi states: "There are numerous parents in the world but few are magnanimous.... There are numerous teachers in the world but few are magnanimous.... There are many rulers in the world but few are magnanimous." 43 Mozi believed that it was only on account of Heaven that the highest ethical practitioners can exist; it is only on account of tian that $f a$ 法 [norms, laws, a legal system] can exist because the love of Heaven for all the world's living things is a pure and unselfish love. Indeed, the love of Heaven for human beings does not seek to use people as a means to something else but takes the form of a love focused on people for their own sake. This is the root source of utmost value in the universal love ethical philosophy - that is, with "Heaven" as our "Standard."

Then we might ask: but what are the characteristics of "Heaven"? And how might we follow Heaven? The chapter "On the Necessity of Standards" states: "Heaven is all-inclusive and impartial in its activities, abundant and unceasing in its blessings, and lasting and untiring in its guidance." ${ }^{44}$ We can here observe that Heaven's love is granted universally to all people in a manner akin to sunlight or rain. This is the universal nature of "all-inclusive and impartial in its activities." Furthermore, "abundant and unceasing in its blessings" is a reference to the unselfish nature of this love, which has something of an impersonal or objective nature. We can further observe the clarity and permanence of Heaven from the term "lasting and untiring in its guidance."45 Thus, "Heaven" as a source of value has universal, objective, clearly defined, and permanent characteristics, such that it can make it a standard of conduct for human beings.

Han Fei drew on Mohist theory on "On the Necessity of Standards" but, instead, emphasized $f a$ [the standard] as the provider of guiding norms, rather

43 Translation taken from “法儀-On the Necessity of Standards," https://ctext.org/mozi/ on-the-necessity-of-standards/.

44 Translation taken from “法儀-On the Necessity of Standards," https://ctext.org/mozi/ on-the-necessity-of-standards/.

45 Wang Zanyuan 王讚源, Mozi 墨子 (Taipei: Dongda tushu gongsi, 1996), 85. 
than a "Heavenly based" fayi. Thus, when $f a$ is used as the normative basis or underlying principle for everything, all human beings would stand before the law as equals.

The "Having Regulations [You du 有度]" chapter in the Han Fei zi states:

Thus, every intelligent ruler ordered his ministers never to realize their wishes outside the realm of law and never to bestow their favors inside the realm of law - in short, never to commit any unlawful act. As strict laws are means to forbid extra-judicial action and exterminate selfishness and severe penalties are means to execute decrees and censure inferiors, legal authority should not be deputed to anybody and legal control should not be held behind the same gate. Should legal authority and control be kept in common by both ruler and minister, all varieties of wickedness would come into existence. If law is of no faith, its enforcement by the ruler is absurd. If penalty is not definite, culprits cannot be overcome. Hence the saying: "The skillful carpenter, though able to mark the inked string with his surveying eyes and calculating mind, always takes compasses and squares as measures before his marking; the great genius, though able to accomplish his task with swift move, always takes the law of the early kings as the ruler before his accomplishment." Thus, if the inked string is straight, crooked timbers will be shaved; if the water-level is even, high gnarls will be planed down. Similarly, if weights and balances are well hung up, what is too heavy will be decreased and what is too light will be increased; once pecks and bushels are established, what is too much will be decreased and what is too little will be increased. Hence to govern the state by law is to praise the right and blame the wrong. The law does not fawn on the noble; the string does not yield to the crooked. Whatever the law applies to, the wise cannot reject nor can the brave defy. Punishment for fault never skips ministers, reward for good never misses commoners. ${ }^{46}$

This indicates Han Fei's belief in a supreme authority governing the norms of human behavior, that is, a system of laws under which all people - whether rich or poor - stand as equals. Whereas Mozi discussed the equality of humankind with reference to universal love, Han Fei, instead, looks to "legal governance" [fazhi 法治] in his discussion of it.

The "Six Contrarieties [Liu fan 六反]" chapter in the Han Fei zi records:

46 Translation taken from Liao, The Complete Works of Han Fei Tzŭ, 27-8. 
The sage, in governing the people, deliberates upon laws and prohibitions. When laws and prohibitions are clear and manifest, all officials will be in good order. He makes reward and punishment definite. When reward and punishment are never unjust, the people will attend to public duties. If the people attend to public duties and officials are in good order, then the state will become rich; if the state is rich, then the army will become strong. In consequence, hegemony will be attained. The enterprise of the Hegemonic Ruler is the highest goal of the lord of men. With this highest goal in view the lord of men attends to governmental affairs. Therefore, the officials he appoints to office must have the required abilities, and the rewards and punishments he enforces must involve no selfishness but manifest public justice to gentry and commoners. ${ }^{47}$

Here, we can observe the normative role played by the law on people's behavior, particularly in its "commendation and punishments system" [shangfa 賞罰]. Moreover, the law must have a just and fair nature, and officials who execute the law must also be public minded and not selfish or corrupt (comparable to the "Heaven" and gui 鬼 [demon, spirit, devilish] natures noted by Mozi).

\subsection{The Han Fei zi's Use and Repurposing of Mozi's “Identification with the Superior"}

The chapter "Identification with the Superior II [Shangtong zhong 尚同中]" in the Mozi states: "[Heaven] chose the virtuous, sagacious, and wise in the world and crowned him emperor, charging him with the duty of unifying the wills in the empire." 48 The chapter "Identification with the Superior I" also states:

If, however, the people all identify themselves with the Son of Heaven but not with Heaven itself, then the jungle is still unremoved. Now, the frequent visitations of hurricanes and torrents are just the punishments from Heaven upon the people for their not identifying their standards with the will of Heaven. ${ }^{49}$

We observe here that the political order Mozi has constructed has a rather pyramidal structure, with Heaven at the highest level and ordinary people

47 Translation taken from Liao, The Complete Works of Han Fei Tzŭ, 304-5.

48 Translation taken from “尚同中-Identification with the Superior II," https://ctext.org/ mozi/identification-with-the-superior-ii/.

49 Translation taken from “尚同上-Identification with the Superior I," https://ctext.org/ mozi/identification-with-the-superior-i/. 
at the bottom, between which we find various officers of the state of various ranks - the highest of which is the emperor, or son of Heaven [tianzi 天子], who must also follow Heaven's commands. The supreme position of the political pyramid envisaged by Han Fei was occupied by the monarch [guojun 國君], who enjoyed supreme authority. These conceptions may have had something to do with the philosophers' respective eras: Mozi lived during the early Warring States period and Han Fei the latter part of the same period, when the flames of war between the different princes of each kingdom burned with ever greater intensity. We could also look at the way in which the specific instructions communicated in the "will of Heaven" in Mohist thought were rather ambiguous in nature and appeared to Han Fei to be substantially less clear and effectively executed than a monarch's ordinances. Han Fei did not believe in ghosts and spirits [guishen 鬼神] and hence relegated the supreme authority to the monarch. In the Mohist political order, subordinates should follow the instructions of their superior, provided that noble or sage-like people [xian$z h e$ 賢者] occupied these positions. However, if there were areas in which the superior officer of the state did not satisfy Heaven's will, then provision was made for this situation to be remedied. This system takes the "will of Heaven" as the standard by which to appraise good and evil.

The chapter "Identification with the Superior I" states:

What the superior thinks to be right all shall think to be right; what the superior thinks to be wrong all shall think to be wrong. When the superior is at fault there shall be good counsel, when the subordinates show virtue there shall be popular recommendation. To identify oneself with the superior and not to unite oneself with the subordinates - this is what deserves encouragement from above and praise from below. On the other hand, if upon hearing good or evil one should not report to a superior; if what the superior thought to be right one should not think to be right; if what the superior thought to be wrong one should not think to be wrong; if when the superior was at fault there should be no good counsel if when the subordinates showed virtue there should be no popular recommendation; if there should be common cause with subordinates and no identification with the superior - this is what deserves punishment from above and condemnation from below. The superior made this the basis of reward and punishment. He was clear-sighted and won his people's confidence. ${ }^{50}$ 
We observe that a certain relationship exists between the "will of Heaven" and the "opinions of the people" [minyi 民意]: commendations and punishments that comply with the will of Heaven will be praised by the people; commendations and punishments that do not comply with the will of Heaven will, by contrast, meet with the opprobrium of the masses. This provides us with a perspective on the existence of a certain association between the opprobrium or support of the people and the "will of Heaven." In other words, in Mozi we find a single transcendent and universal criterion that serves as a basis for commendation and punishment by the government.

Han Fei learned from and emulated Mohist political philosophy. Although he did not provide any transcendent basis after appointing supreme authority to the monarch, he continued to maintain the requirement that commendations and punishments must be consistent with the views of the masses in order for governance to be effective. The "Eight Canons [Bajing 八經]" chapter in the Han Fei zi states:

Generally speaking, the order of All-under-Heaven must accord with human feelings. Human feelings have likes and dislikes, wherefore reward and punishment can be applied. If reward and punishment are applicable, prohibitions and orders will prevail and the course of government will be accomplished. ${ }^{51}$

We see here that Han Fei places importance on the fact that commendations and punishments must correspond to behavior (whether positive or negative) and that the commendation and punishment by the monarch must comport with the ethical aspects of human feelings.

\subsection{The Han Fei zi's Recognition of Mozi's Innovative Philosophy}

The “Geng Zhu 耕柱” chapter in the Mozi records:

Gong Mengzi said: "The superior man does not create but transmits." Mozi said: Not at all. The most unsuperior men do not transmit the good of old and do not create any good for the present. The less unsuperior men do not transmit the good of old, but will bring out the good which he possesses for the sake of praise. Now to transmit but not to create is not different from creating without transmitting. It seems to me what good there

51 Translation taken from Liao, The Complete Works of Han Fei Tzŭ, 314. 
is of old one should transmit it; what good there is to be for the present, one should institute it, so that the good may increase all the more. ${ }^{52}$

As we observe in this passage, Mozi was not blindly tied to the philosophies of the ancients but, rather, was willing to pursue innovative ideas.

The "Canon II" states: "In the case of Yao's $y i$ [right conduct, righteousness, and justice], it is heard of in the present but is located in the past, and these are different times. The explanation lies in what is yi being two."53 Mozi thus evinces a strong awareness of the differences between the days of antiquity and those of the "present" and will not be "swept up" by mere mimicry of whatever is ancient. ${ }^{54}$

The "Anti-Confucian [Feiru 非儒]" chapter in the Mozi states:

The Confucian says: "The superior man must be ancient in mode of speech and in dress before he can be magnanimous." We answer him: The so-called ancient speech and dress were all modern once. When the ancients first used that speech and wore that dress they would not be superior men (according to the Confucianists' criteria). Do you therefore mean to say that one has to wear the dress of the non-superior man and speak the speech of the non-superior man before he can be magnanimous? ${ }^{55}$

Although Mozi's "method of three standards" indeed have aspects grounded in antiquity, for example, Mozi's "We should look to the deeds of the ancient sagekings," or based in antiquity, for example, "We should examine the deeds of the sage-kings," ${ }^{56}$ these canons still have an abundance of original thinking. For instance, Mozi highly disapproves of certain bygone sensibilities, such as those of Confucians who declared that a gentleman must follow the same manner of speaking and dress as those of old who were truly considered "gentlemen." Mozi ingeniously draws readers' attention to the fact that those ancients were originally responsible for inventing new manners of speech and clothing by inference and, so, are thereby revealed to have been innovators themselves. This line of thinking also shows up in Han Fei's philosophy.

\footnotetext{
52 Translation taken from “耕柱-Geng Zhu," https://ctext.org/mozi/geng-zhu/.

53 Translation taken from Johnston, The Mozi, 459 .

54 Wang Zanyuan 王讚源, Mojing zhengdu 墨經正讀 [A Right Reading of the Mohist Canon] (Shanghai: Shanghai kexue jishu wenxian chubanshe, 2011), 133 .

55 Translation modified slightly from “非儒下-Anti-Confucianism II," https://ctext.org/ mozi/anti-confucianism-ii/.

56 Translation taken from “非命上-Anti-Fatalism I," https://ctext.org/mozi/anti-fatalism-i/.
} 
The "Five Vermin [Wu du 五冨]" chapter in the Han Fei zi states:

Hence the saying: "There are as many situations as there are generations." In the time of Shun the Miao tribes disobeyed. When Yu moved to send an expedition against them, Shun said: "By no means. As our Teh [De] is not great, any resort to arms is not in accord with the Tao [Dao]." Thenceforth for three years he cultivated the ways of civic training and then he made a parade of shields and battle-axes, whereupon the Miao tribes submitted. In a subsequent age, during the war with the Kung-kung 共工 tribes men using short iron weapons hardly reached their enemies while those whose armor was not strong suffered bodily injuries. It means that mere parade with shields and battle-axes once effective in olden times is not so at present. Hence the saying: "Situations differ, so measures change." Men of remote antiquity strove to be known as moral and virtuous; those of the middle age struggled to be known as wise and resourceful; and now men fight for the reputation of being vigorous and powerful. ${ }^{57}$

Han Fei took the view that if the times changed, then the situation must change as well. If the situation changed, then so too must related matters. We observe Han Fei's perspective on history here and the way in which the present passes into the realm of antiquity [biangu 變古], which is also an affirmation of Mozi's creative tendencies.

The "Facing the South [Nan mian 南面]" chapter in the Han Fei zi states:

Those who do not know the right way to political order, always say, "Never change ancient traditions, never remove existing institutions." Change or no change, the sage does not mind. For he aims only at the rectification of government. Whether or not ancient traditions should be changed, whether or not existing institutions should be removed, all depends upon the question whether or not such traditions and such institutions are still useful for present-day political purposes. ${ }^{58}$

This section highlights Han Fei's perspective on suitable criteria to judge whether to change or not to change a standard: will a change promote effective governance of the country? Han Fei not only approved of Mozi's innovative ideas, but even pursued an improved state of affairs with greater zeal. These three areas highlighted provide us with a sufficient glimpse into Han Fei's usage and

57 Translation taken from Liao, The Complete Works of Han Fei Tzŭ, 326.

$5^{8}$ Translation taken from Liao, The Complete Works of Han Fei Tzŭ, 90. 
modification of Mohist philosophy during the latter Warring States period and furnishes us with a stronger understanding of the profound impacts wrought by Mozi in this period of history.

\section{Foundations and Directions in the Modern Transformation} of Mohism

\subsection{Today's Era}

Since the terrorist attack on New York City on September 11, 2001, terrorism has become part of the global consciousness, and so has a renewed appreciation for potential threats posed by other terrorist organizations. The Security Council of the United Nations swiftly established the Counterterrorism Committee that year, to which was added the Counterterrorism Committee Executive Directorate in 2004 to carry out anti-terrorist work on a global scale; its missions include legislative penalties for financing terrorist activities, to block all support for terrorism, sharing of counterterrorism intelligence among countries, and promotion of international cooperation in investigations on terrorist organizations. Nevertheless, terrorist attacks have been committed one after another across a broad range of jurisdictions, from Paris (France) to Ankara (Turkey) to Brussels (Belgium). It appears the world has entered a vicious cycle of increasing terrorism and increasingly vigorous countermeasures. This reminds us of a section of the chapter "On Ghosts III":

The people practice immorality and wickedness and become rebellious. Thieves and bandits with weapons, poison, water, and fire hold up innocent travelers on the highways and the bypaths, robbing them of their carts and horses, coats and fur coats, to enrich themselves. All these start therewith [with the passing of the sage-kings]. And so the world falls into chaos. 59

The picture presented here is not entirely dissimilar to the world we see today, over two millennia later.

From an environmental perspective, not only has humanity failed to be aware of and appreciate the precious bounty in our possession and to cherish Mother Nature but, instead, it has in many ways abused our natural environment and wasted natural resources in a rather rapacious manner. Many

59 Translation, slightly modified, taken from “明鬼下-On Ghosts III,” https://ctext.org/ mozi/on-ghosts-iii/. 
so-called natural disasters have their roots in human activity (e.g., earthquakes, tsunamis, floods, and landslides), in which human beings are responsible for irresponsible land clearing and logging, the establishment of housing in floodprone areas, generating significant amounts of air pollution, and creating voluminous amounts of refuse that have contaminated water supplies. These and other such issues are the subject of never-ending reports in the media: global warming, increasing destruction of the ozone layer, reduction in the world's forests, the extinction or near extinction of protected species, various energy crises, and so on. Many scientists currently take the view that humanity's improper use of technology and the destruction of our environment may well cause permanent and lasting damage to the ecosystem and could even lead to the destruction of human civilization as we know it.

Manmade destruction, leading to instability in global ecosystems, and the increasing severity of truly global problems and crises are publicly visible and knowable facts. It is certainly not easy for humanity to arrive at a common consensus or achieve our objectives. However, perhaps we can find something of a guide in the ancient wisdom of China's Mozi and his spirit of "universal love" to find a path out of today's global disorders.

\subsection{The Basis of the Modern Mohist Transformation}

The purpose of providing an overview in the preceding paragraphs about preQin era critiques of Mohist philosophy and an examination of the impact of Mohism on the various thinkers and schools of the day is to highlight the fact that the transformation of a philosophical system in antiquity into a modern trend must take into consideration the interactive relationship between different schools' philosophies and the multitudinous interwoven "threads of influence." Thus, it behooves us to locate the basis of Mohism's modern transformation with reference to the changing philosophical trends in the pre-Qin era and process of critique and debate between these different schools of thought as we appreciate the interactive relationships between the Mohists and the Confucians, Daoists, and Legalists at the time.

Beginning with the relationship between Mozi and Confucian philosophy, the chapter “Overview of the Essentials [Yao lue xun 要略訓]" in the Masters from Huainan [Huainanzi 淮南子] states:

Master Mo studied the work of the Confucians and received the techniques of Confucius. [However,] he regarded their rituals to be worrisome and inappropriate, their lavish funerals to be wasteful of resources, impoverishing the people, while their lengthy mourning periods harmed 
life and impeded undertakings. Thus, Master Mo rejected the Way of the Zhou dynasty and used the regulations of the Xia dynasty. ${ }^{60}$

Judging from these sentiments, it appears that Mohist philosophy diverged from Confucian thought due to dissatisfaction with the "original" philosophy, with the unreasonable aspects criticized and improved and the reasonable aspects expanded and more deeply explored. Hence, an integrated Confucian-Mohist perspective should prove helpful to a more thorough examination of its worth today and might have something of value to offer by way of reflection on or application to modern society. Hence, the modern transformation of Mohist thought must incorporate the intellectual resources of Confucian philosophy.

As Han Yu reflected:

The Confucians ridicule the Mohists' "identification with the superior," "universal love," and "conformity to the sages," belief in the spirits and celestials, and so forth, and yet Confucius himself showed reverence toward officials of state and would speak no evil words against the officials of any state. Is not Confucius' ridicule of tyrannical ministers in his Spring and Autumn Annals a reflection of [or an attitude of] "identification with the superior?" Are not Confucius' ideas around caring for the people, carrying out acts of benevolence, and identification of the Sage with the broad giving of alms to the people a reflection of universal love? Could not Confucius' praise for disciples on the basis of talent, ethical conduct, speech, political affairs, and literary learning [the four subjects] and view that to die without establishing a good name to be a source of shame akin to conformity to the sages? Confucius advocated that we should be reverent when offering worship to ancestors as if those same ancestors were standing before us, and ridiculed those false and nongenuine worshippers, saying, "I shall benefit from the ancestors' bounty by this worship." Is that not [in some way] a demonstration as to the existence of the spirits and celestials? Both the Confucians and Mohists give praise to Emperor Yao and Emperor Shun and both oppose Jie of Xia and King Zhou. Both schools focus on the cultivation of an upright heart in the governance of the nations. How is it that we have come to [the situation] today where neither school endorses the other? I believe

6o Translation taken from John S. Major, Sarah A. Queen, and Andrew Seth Meyer et al., trans., The Huainanzi: A Guide to the Theory and Practice of Government in Early Han China (New York: Columbia University Press), 998-99. 
that the split came about through the students of posterity and was so in order for them to elevate their teachers' theories to others. This was not, in fact, a true reflection of their masters' thinking. Confucius must look at Mencius' thinking. Mencius must look to Confucius' thinking. Such a mutual examination is necessary to adequately conceptualize each school's respective views. ${ }^{61}$

These paragraphs highlight the manifold similarities and sympathies between the two scholars, whose views could well be integrated to an extent.

Turning to another domain of Mencius' theory on the good nature of human beings [xingshan lun 性善論], we can read about Mencius' example demonstrating the existence of a "commiserating heart" [ceyin zhixin 惻隱 之心] common to humankind in his argument:

If men suddenly see a child about to fall into a well, they will without exception experience a feeling of alarm and distress and that they will feel so, not as a ground on which they may gain the favor of the child's parents, nor as a ground on which they may seek the praise of their neighbors and friends, nor from a dislike to the reputation of having been unmoved by such a thing. ${ }^{62}$

It is clear that the impetus of the "commiserating heart" triggered by human nature is a type of love that exceeds the narrow limits of blood relationships and disparities between human beings but, instead, points in the direction of all humankind. Although Mencius was also a vehement critic of Mozi's "universal love" philosophy, it is also interesting to see hints of the "universal love" spirit shining through the core precept of the "theory that people are basically good" in Confucian philosophy. Thus, the modern Mohist transformation should take care to emphasize the compatibility between the foundations of Confucian thought and Mozi's "universal love."

Xunzi's classic example that "everyone is born with desires" [ren shenger youyu 人生而有欲] in his theory that "humanity has an evil disposition" [xing $e$ lun 性惡論] is also very connected to Mohist philosophy, given that Mozi also acknowledged that human beings have an innate yearning or disposition to cleave to the beneficial and avoid the ill. Mozi's "universal love," after all,

61 Han $\mathrm{Yu}$ 韓愈, Han Changli wenji jiaozhu 韓昌黎文集校注 [Collation of the Han Changli Collection], coll. Ma Qichang 馬其求 (Shanghai: Shanghai guji chubanshe, 1986), 39-40.

62 Translation taken from “公孫丑上-Gong Sun Chou I," https://ctext.org/mengzi/gong -sun-chou-i/. 
is meant to be a kind of desire that tends to satisfy the mutual interests of all human beings. Mozi believed that human relationships in an ideal society would reward individual contributions to society and others in one form or another and that if every individual's value to society could be acknowledged as such by that society, then society would find a way, through various channels, to satisfy individuals' corresponding and reasonable needs. The "universal love and mutual aid" advocated by Mozi and his principle of equal and mutual recompense are precisely aimed at the establishment of such an ideal society. Hence, a modern transformation of Mohism must emphasize the positive results of disseminating the practice and philosophy of "universal love and mutual aid."

Turning to Zhuangzi's critique of Mozi as having adopted overly transcendent and unrealistic philosophical positions, if we were to walk in the Mohists' shoes and survey the land at a time that the practical concerns of everyday survival were still paramount, we might find the elevation of a small minority of individuals to a higher ethical plane helpful to relatively few sage-like individuals but much less useful from the perspective of helping the general populace with their problems. Mozi evidently wanted to help solve real-life problems and to build a philosophical framework for doing so, hence it was not possible for him to avoid theoretical presuppositions and certain criteria with which to make value judgments. We need only look to the recognition in Han Fei's philosophy for Mozi's creative thinking to see the ways in which a modern Mohist transformation must be adaptable to circumstances and free to adjust its method of "procuring benefits for the world and eliminating its calamities" in a self-aware manner as dictated by the times. Hence, a modern Mohist transformation must adapt to circumstances while remaining firmly grounded in an unchanging "universal spirit of love."

\subsection{Directions for the Modern Mohist Transformation}

The modern Mohist transformation is directed at the ideals for which the philosophy strives. What are these ideals? Simply put, they are "peace all under Heaven" [tianxia taiping 天下太平] and "love between all human beings" [renren xiang'ai 人人相愛]. Naturally, we must seek that which is beneficial and eliminate that which is harmful to achieve the former and promote a philosophy of "universal love and mutual aid" and the idea that only with this powerful mutual love and mutually beneficial arrangements between individuals can we promote "peace all under Heaven" to foster the latter. Our ideals are formed out of the deficiencies and imperfections of the everyday to resolve issues in ordinary life and to improve and ameliorate unreasonable circumstances and unjust situations. Thus, Mozi highlights in his chapter "Universal Love III" that 
the great evils in the land have come from people's pursuit of their own selfish ends and self-interest, and people who loved only themselves, rather than others. Hence, the work of "procuring benefits for the world" consists of changing “a limited or particular, localized love" [bie ai 別愛] into a "bigger picture" universal love by conveying to individuals a superior understanding of the logic that loving others is beneficial not only to the other but also to oneself and by addressing or seeking to reverse the selfish and self-interested aspects of human nature.

The Mohist ideal of "accomplishing great benefits for humanity" uses a method of "universal love" in which individuals help one another for life to provide everyone with the space to survive or even thrive. As stated in the chapter "Universal Love III":

with universal love as our standard, then attentive ears and keen eyes will respond in service to one another, then limbs will be strengthened to work for one another, and those who know the Dao will untiringly instruct others. Thus the old and those who have neither wife nor children will have the support and supply to spend their old age with, and the young and weak and orphans will have the care and admonition to grow up in..$^{63}$

In this idealized picture of society, we find that disadvantaged and vulnerable groups receive care and protection, and capable individuals in society are proactively willing to help others. As stated in the chapter "Li Yun 禮運" in the Classic of Rites [ LiJi 禮記]:

Thus men did not love their parents only, nor treat as children only their own sons. A competent provision was secured for the aged till their death, employment for the able-bodied, and the means of growing up to the young. They showed kindness and compassion to widows, orphans, childless men, and those who were disabled by disease, so that they were all sufficiently maintained. ${ }^{64}$

These idealized conceptions all feature a spirit of equality between all individuals.

63 Translation taken from “兼愛下-Universal Love III," https://ctext.org/mozi/universal -love-iii/.

64 Translation taken from “禮運-Li Yun,” https://ctext.org/liji/li-yun/. 
A utilitarian or even "greed is good" worldview has become extremely prevalent or even dominant in today's society, an attitude that has no doubt also spurred numerous unwanted changes at a familial and social level. Political, economic, and technological development and so on has led to structural changes in traditional modes of human relationship. It is at such times that we might well look to the wisdom of Mohist thought as we seek to adapt ourselves to such changes and better find our place in the onslaught of the popular philosophies of the era versus traditional thinking with the use of the ethical, logical, and practical characteristics of Mohist thought. In short, we might want to consider the use of Mozi's "names and disputation" method as we discourse with differing philosophical conceptions and try to promote and realize a "universal love" spirit integrated with Confucian philosophy.

The modern Mohist transformation has three key aspects:

The first is that "procuring benefits for the world and eliminating its calamities" consists of the resolution of local issues with a global mindset. As Mozi's perspective encompasses "all under Heaven," this means looking at our entire "global village," in modern parlance. The object of Mozi's care and concern is the benefit of all people under Heaven, or all of humanity. Why is it so important to resolve local issues from a global perspective? If we do not look at local problems from a vantage point that takes the whole into account, then solutions may well lead to further, more severe issues. For example, the use of overwhelming force to counter terrorist groups may have proved effective in the short term but has now perhaps helped to seed further terrorist elements around the world, leading to a more widespread lack of security. Hence, the use of a "universal love" method - being inclusive, understanding, or even forgiving toward individuals with respectful attitudes - is a method that should not be overlooked in today's fight to nullify terrorist ideology.

Second, it involves trying to promote a global philosophy of peace and global environmental awareness via "universal love and mutual aid." Addressing environmental issues calls in particular for a holistic perspective of world affairs. For instance, if our "solution" to a local issue of contamination or pollution is simply to emit or transport exhaust gas, contaminated water, metal, or discarded nuclear fuel abroad, then the result might ultimately prove harmful to every human being on the planet, including the emitters and transporters themselves. The modern Mohist must take care to emphasize the interactivity binding different individuals or entities together in the promotion of global peace, and although two individuals, two groups, or two countries involved in "universal love and mutual aid" are two, they are also, in another sense, one. 
Although it might seem that you and I are very much separate, the reality is that we are part of a common community of shared concern, and if we do not find arrangements with mutually beneficial outcomes or extend the hand of respect and compassion toward weaker parties, then harm will undoubtedly be visited on those who might currently benefit from this system in due course, as humanity is part of an integrated whole, and there is only one "global village."

Third, the modern Mohist seeks to promote technological integration in the spirit of Mozi's "identification with the superior" and "Mohist methods of thinking" so as to aggregate cultural, social, and natural scientific thought and philosophy into an integrated form in establishing global educational and learning systems. We would do well to emulate Mozi's attempts at traveling far and wide to promote his message of "universal love" and "non-aggressive philosophy" and seek to train outstanding scholars attuned to Mohist philosophy more broadly to promote the "universal love" spirit through modern information technologies and the internet. In the same vein, we might aspire to integrate knowledge and learning of other domains fields into Mohist educational materials in the hope that Mohist thinking will one day be incorporated into the educational systems of every country to expedite the adoption of the spirit of "universal love" as a common and universal value and to instill the common goal that "we are one" [tianxia datong 天下大同] into the objectives of all countries.

\section{Translated by William Green}

\section{Works Cited}

Chan, Wing-Tsit. A Source Book in Chinese Philosophy. Princeton: Princeton University Press, 1973.

Defoort, Carine. "Do the Ten Mohist Theses Represent Mozi's Thought? Reading the Masters with a Focus on Mottos." Bulletin of the School of Oriental and African Studies 77, no. 2 (2014): 337-70.

Han Yu 韓愈. Han Changli wenji jiaozhu 韓昌黎文集校注 [Collation of the Han Changli Collection]. Collated by Ma Qichang 馬其昶. Shanghai: Shanghai guji chubanshe, 1986.

Hutton, Eric L. Xunzi, the Complete Text. Princeton: Princeton University Press, 2014. Johnston, Ian. The Mozi: A Complete Translation. New York: Columbia University Press, 2010.

Lee, Hsien-chung 李賢中. Moxue lilun yu fangfa 墨學理論與方法 [Mohism: Theory and Method]. Taipei: Yangzhi wenhua shiye gufen youxian gongsi, 2003 . 
Liao, W. K., trans. The Complete Works of Han Fei Tzŭ with Collected Commentaries. London: Probsthain, 1939.

Major, John S., Sarah A. Queen, and Andrew Seth Meyer et al. trans. The Huainanzi: A Guide to the Theory and Practice of Government in Early Han China. New York: Columbia University Press, 2010.

Sun Yirang 孫詒讓. Mozi jiangu 墨子閒詁 [Inquiries and Interpretations of the Mozi]. Beijing: Zhonghua shuju, 1954.

Sun Zhongyuan 孫中原, ed. Moxue yu xiandai wenhua 墨學與現代文化 [Mohism and Modern Culture]. Beijing: Zhongguo guangbo dianshi chubanshe, 2007.

Wang Xianqian 王先謙. Xunzi jijie 荀子集解 [Collected Explanations of the Xunzi]. Collated by Shen Xiaohuan 沈嘯寰 and Wang Xingxian 王星賢. Beijing: Zhonghua shuju, 1988.

Wang Zanyuan 王讚源. Mozi 墨子. Taipei: Dongda tushu gongsi, 1996.

Wang Zanyuan 王讚源, ed. Mojing zhengdu 墨經正讀 [The Right Reading of the Mohist Canon]. Shanghai: Shanghai kexue jishu wenxian chubanshe, 2011.

Yan Lingfeng 嚴靈峰. Mozi jianbian 墨子簡編 [Mozi Compendium]. Taipei: Shangwu yinshu guan, 1995 . 